\title{
Det svære forsvar af sociale rettigheder
} Hatla Thelle

\author{
Kina har for første gang været til uddybende \\ møde i FN's Komité for Økonomiske, Sociale og \\ Kulturelle Rettigheder, der arbejder i et vanskeligt \\ krydsfelt
}

I et forårsvarmt Genève april 2005 var Kina for første gang udsat for eksamination (eller møde med - alt efter hvordan man vælger at betragte seancen) i FN's Komité for Økonomiske, Sociale og Kulturelle Rettigheder (i det efterfølgende kaldet Komitéen). Komitéen er ansvarlig for håndhævelsen af den Internationale Konvention om Økonomiske, Sociale og Kulturelle Rettigheder fra 1966 (fremover kaldet Konventionen), der trådte i kraft 1976 efter at 35 lande havde tiltrådt den.

Kina er jo oftest på dagsordenen i de vestlige medier $i$ anledning af grove krænkelser af civile og politiske rettigheder som ytrings-, religionsog forsamlingsfrihed. Af den grund kan det måske undre nogen, at Kina i det hele taget er at finde blandt underskriverne på FN's menneskerettighedskonventioner. Men Riget i
Midten har faktisk underskrevet næsten alle de vigtigste dokumenter. Kravene til underskriverne er heller ikke specielt høje.

FN-systemet har oprettet specielle komitéer, som skal overvåge de enkelte landes overholdelse af de konventioner, de har underskrevet, samt generelt fortolke konventionerne, hvis ordlyd ofte er temmelig vag. Komitéens medlemmer vælges af medlemslandene, men er uafhængige af deres egne landes regeringer.

De kontrollerer overholdelsen af den pågældende konvention ved at behandle rapporter fra de lande, der har tiltrådt den. Fortolkningerne bliver udsendt i form af såkaldte Generelle Bemærkninger, hvor Komitéen behandler et udvalgt emne eller en bestemt konventionsartikel og gør rede for, hvordan Komitéens medlemmer forstår den pågælden- 
de artikel eller det pågældende problemområde.

I en Generel Bemærkning angående medlemsstaternes forpligtelser redegør Komitéen for sit principielle udgangspunkt i bedømmelsen af de enkelte landes rapporter: "I spørgsmålet om politiske og økonomiske systemer er Konventionen neutral og dens principper kan ikke beskrives præcist som værende bygget udelukkende på behovet for eller ønskværdigheden af et socialistisk eller et liberalistisk system; en planøkonomi eller en kapitalistisk økonomi; eller på nogen anden specifik tilgang." (CESCR Generel Bemærkning nr. 3, paragraf 8).

Konventionen definerer sociale rettigheder i store træk som retten til arbejde, social sikkerhed, en rimelig levestandard, sundhed og uddannelse. I Generel Bemærkning nr. 3 står således, at sociale rettigheder kan beskyttes på mange forskellige måder alt efter det enkelte lands politiske og økonomiske system.

Det fremgår samtidig, at det i sidste ende er staternes forpligtelse, at de grundlæggende sociale rettigheder beskyttes. Det vil primært sige, at hvis et menneske af en eller anden grund er ude af stand til at forsørge sig selv, er det statens pligt at se til, at et basalt livsgrundlag skaffes til veje. Hvordan dette sker, er med visse begrænsninger op til det enkelte lands regering. Der er tale om to former for forpligtelser: en 'forpligtelse til en handling' og 'forpligtelse til et resultat' (Maastricht Guidelines on Violations of Economic, Social and Cultural Rights, January 1997, guideline no. 7. Human Rights Quarterly 20(1998), s. 715.).

Heraf følger både, at regeringer skal vedtage love og oprette institutioner og administrative strukturer, der kan beskytte deres borgere mod nød og samtidig skal sikre et minimum af mad, boligforhold og uddannelse. Det vil sige, at sociale rettigheder beskyttes gennem socialpolitiske indsatser fra staternes side. Disse kan bestå i, at regeringen selv skaffer de nødvendige ydelser eller sørger for, at andre gør det, inklusive via internationalt samarbejde, idet rige lande er forpligtede til at bistå lande med få ressourcer.

I selve Konventionens art. 4 er dog en modifikation af 'neutraliteten,' idet det siges, at rettighederne kan begrænses ifølge lov og i overensstemmelse med, hvad 'der skønnes nødvendigt i et demokratisk samfund'. Der er på den måde en modsætning mellem den hævdede neutralitet i forhold til politiske systemer og kravet om, at begrænsningerne ikke må overstige dem, der er nødvendige i et demokrati. Retten til at definere nødvendigheden ligger hos Komitéen.

\section{Konventionen om rettigheder}

Konventionen om Økonomiske, Sociale og Kulturelle rettigheder er tiltrådt af ca. 150 ud af verdens 191 
lande, inklusive så fattige lande som Bangladesh, Cambodja og GuineaBissau samt islamiske lande som Iran og tidligere Østblok-lande som Usbekistan og Aserbajdsjan. Flere store politisk betydningsfulde lande har ikke tiltrådt Konventionen, for eksempel er Malaysia, Indonesien, Sydafrika og Saudi-Arabien ikke medlemmer. Og USA har kun underskrevet konventionen - helt tilbage i 1977 - men ikke tiltrådt den. Heller ikke Cuba, som har et efter forholdene udmærket socialt system, er med i flokken.

Tilbage står, at en overvejende majoritet af verdens lande har forpligtet sig gennem FN-systemet til at sikre deres borgere social tryghed. Deres evner til at opfylde forpligtelserne og måderne at gøre det på er imidlertid meget forskellige.

Der er fra internationalt hold ingen begrænsninger på, hvilke lande der kan accepteres som medunderskrivere eller medlemmer af Konventionen. Og det til trods for, at der i konventionen selv og i ovennævnte Generelle Bemærkning faktisk findes nogle enkelte krav til karakteren af de interne styreformer. Konventionens artikel 4, som er citeret ovenfor, afspejles i punkt $8 \mathrm{i}$ ovennævnte Bemærkning, som siger, at Komitéen ikke kræver eller udelukker nogen form for politisk eller økonomisk system bortset fra “....at det er demokratisk og alle menneskerettigheder derved respekteres". Kravet om demokrati burde udelukke lande som Kina eller Vietnam, der begge har tiltrådt Konventionen i hhv. 2001 og 1982.

Det kunne være interessant i den forbindelse at se på Komitéens konklusioner på disse landes rapporter: Vietnam er bagud med to rapporter til Komitéen, som skulle have været afleveret i hhv. 1995 og 2000 mens Kina har afleveret sin første rapport i 2003; det er 'forsvaret' af den, der fandt sted i Geneve i foråret 2005. Efter at have studeret de enkelte landerapporter og eksamineret en delegation i dem under de halvårlige samlinger i Geneve, udgiver Komitéen en såkaldt 'Konkluderende Observation," der belyser landets overholdelse af bestemmelserne i Konventionen, som Komitéen nu anskuer den.

Denne artikel vil gennemgå de 'Konkluderende Observationer' om en række lande i Europa og Asien med henblik på at afdække spændingsfeltet mellem politik og jura, som er et gennemgående tema i det internationale system til beskyttelse af menneskerettighederne.

\section{Konklusioner på landerapporter}

Lande, der er tiltrådt Konventionen, er forpligtet til hvert femte år at aflevere en rapport til Komitéen om overholdelsen. Rapporten bliver læst af Komitéens medlemmer, som frit kan indhente oplysninger fra andre kilder (fx nationale NGO'er eller internationale organisationer) om det pågældende land. Komitéen 
formulerer derefter en liste med spørgsmål stilet til landets regering, som derefter sender en delegation til at mødes med Komitéen ved en af de halvårlige sessioner i Genève.

Her holdes et dag-langt møde, hvor delegationen diskuterer rapporten med Komitéens medlemmer, hvorefter Komitéen offentliggør de Konkluderende Observationer til det pågældende land. I disse opsummeres de positive og negative aspekter af landets overholdelse af konventionen, og Komitéen kommer med en række anbefalinger og spørgsmål, som den gerne vil have besvaret i næste rapport. Principielt set samme mekanismer er i kraft med hensyn til de andre store konventioner. De konkluderende observationer udgør på sæt og vis det internationale systems overvågning og vejledning af de enkelte lande i forhold til den konvention, landet har forpligtet sig til at overholde. Samtidig kan man her finde rammerne for overholdelse udstukket.

En gennemgang af de konkluderende observationer fra 15 lande tegner følgende billede af rammerne inden for menneskeretssystemet med hensyn til statens rolle $\mathrm{i}$ beskyttelsen af borgernes velfærd. De 15 lande er Aserbajdsjan, Danmark, Korea (Nordog Syd-), Finland, Frankrig, Italien, Japan, Kirgisistan, Mongoliet, Nepal, Polen, Tyskland, Ukraine og Kina. Observationerne vedrører den sidste rapportering og er behandlet af Komitéen i perioden fra 1997 til 2003.
Da menneskeretssystemet i sin form er et retligt instrument - del af international ret eller Folkeretten vedrører Komitéens observationer selvfølgelig i overvejende grad det juridiske med følgende punkter:

- Det kommenteres, om Konventionen er inkorporeret i national lovgivning og om der findes eksempler på, at den faktisk bruges af domstolene. Der er her en gennemgående negativ kritik af næsten alle lande for mangel på inkorporering; eller i tilfælde, hvor konventionen er inkorporeret for mangel på eksempler, der viser, at den bliver brugt. Heraf udledes, at kendskabet til konventionen muligvis er ringe i mange landes juridiske systemer.

- Der påpeges lovgivning som klart er i modstrid med Konventionen, fx at børn født uden for ægteskab har andre rettigheder end børn født i ægteskab (Japan), at lesbianisme optræder som en forbrydelse i straffeloven (Kirgisistan), eller at abort er ulovligt og straffes strengt (Nepal).

- Ofte anbefales underskrivelsen af specifikke konventioner, fx en række ILO- konventioner om arbejdsretslige spørgsmål.

Men Komitéen tager også stilling til politiske forhold, som for eksempel nedenstående:

- Det er et standardkrav til alle lande at offentliggøre resultatet af Komitéens overvejelser til de på- 
gældende landes befolkninger samt at tage kontakt til organisationer i civilsamfundet med henblik på løsning af problemerne. Endvidere optræder ofte et krav om at øge kendskabet til Konventionen i befolkningen og i det juridiske system.

- Komitéen opfordrer meget ofte regeringer til at udfærdige handlingsplaner for nye politikker og indsatser på problematiske områder.

- Folkelig deltagelse berøres i mange forskellige sammenhænge.

- Frie valg i overgangssamfund roses som i tilfældet Mongoliet.

- Mangel på strejkeret kommenteres i mange tilfælde, enten på grund af en generel mangel eller udbredte begrænsninger som i Nordkorea og Kirgisistan, eller fordi visse gruppers strejkeret skønnes at være begrænset unødigt som i Danmark og Japan.

- Komitéen opfordrer medlemmer af Verdensbanken og den Internationale Valutafond til at sikre, at disse institutioners politik understøtter Konventionens krav. Komitéen appellerer altså til medlemslandene om at påvirke de globale økonomiske aktører.

På det økonomiske og sociale område kommenterer Komitéen en række forhold negativt, for eksempel:

- Fraværet af garanteret mindsteløn i bl.a. Finland

- Statslig tildeling af arbejde i
Nordkorea, hvor der udtrykkes bekymring for, at denne foranstaltning er i modstrid med retten til frit at vælge sit arbejde.

- Manglende støtte til den uformelle sektor i Aserbajdsjan og negative konsekvenser af privatiseringspolitikken i Ukraine.

- Lønforskelle, for eksempel kønsrelaterede eller baseret på etnicitet, i mange lande

- Høj arbejdsløshed

- Økonomisk politik berøres ikke ofte, dog bemærkes det høje militærbudget i Sydkorea som værende i uoverensstemmelse med et fald i budgetterede udgifter til sociale kerneområder, og der udtrykkes bekymring over en overvægt af private institutioner på sundheds- og uddannelsesområdet. Nordkorea på den anden side opfordres til at støtte private investeringer i uddannelsesområdet for at øge valgmulighederne med hensyn til uddannelse.

- Holdninger i befolkningen som fx fremmedhad i Danmark, Polen og Frankrig, eller kønsdiskrimination på arbejdsmarkedet i stort set alle lande.

Til slut i hvert dokument opsummerer Komitéen sine observationer i generelle vendinger om specifikke emner, som fx om Mongoliet: "Komitéen udtrykker bekymring over nedgangen i udgifter til uddannelse siden 1990 og deraf følgende dalende kvalitet i uddannelsessystemet. 
Specielt bekymrende er det store antal pigebørn, som går ud af skolen for at passe familien derhjemme."

Eller om Nepal: "Komitéen er dybt bekymret over omfanget af fattigdom i Nepal, specielt i landområderne, hvor fattigdom og diskrimination af kvinder er mest udtalt."

Eller om Japan: "Komitéen er bekymret over den stressede og konkurrencefyldte stemning på alle niveauer i uddannelsessystemet, som medfører fravær, sygdom eller endog selvmord blandt skoleelever."

Som det ses kommenterer Komitéen dels den faktiske situation, som den fremgår af statistikker og rapporter, dels handlinger fra regeringernes side som vedtagelse eller ikke vedtagelse af forskellige politikker og endelig kommenteres også traditioner og holdninger hos befolkningerne. Det anses således for at være statens ansvar, når befolkningsgrupper opfører sig efter normer som er i modstrid med Konventionens ånd og/eller bogstav.

\section{Upræcise anbefalinger}

Anbefalingerne er ofte upræcise, men relaterede til specifikke problemstillinger i overensstemmelse med Komitéens mandat, som er ikke at involvere sig i det politiske eller økonomiske system. For eksempel i bemærkningerne om Ukraine påpeges som nævnt, at reformpolitikken har forværret betingelserne for at beskytte økonomiske og socia- le rettigheder og den tilsvarende anbefaling er, at "medlemsstaten vurderer sin økonomiske reformpolitik med henblik på dens konsekvenser for fattigdom og justerer sine programmer, så de i højere grad garanterer økonomiske og sociale rettigheder til svage grupper i samfundet."

Her er altså ikke tale om en stillingtagen til overgangen til markedsøkonomi, men kun til de observerede uheldige konsekvenser af den førte politik. I forbindelse med ovennæunte bekymring over uddannelsessituationen i Mongoliet er anbefalingen at "medlemslandet prøver at behandle problemerne omkring uddannelsessystemet, alene eller gennem internationalt samarbejde." Og i tilfældet med fattigdom i Nepal er anbefalingen, at regeringen etablerer en national kommission til fattigdomsbekæmpelse og i øvrigt inddrager konventionen i regeringens programmer og projekter til at bekæmpe fattigdommen.

Som et eksempel på, hvordan et emne kan blive behandlet gennem hele forløbet kan nævnes spørgsmålet om tvangsflytninger i det nyeste medlem af den asiatiske vækstklub, Kina. Ifølge rapporter fra NGO'er uden for Kina smides folk ud af deres hjem med utilstrækkelig eller ingen kompensation for at give plads for nye industrier. Dette forhold nævnes ikke i den kinesiske regerings rapport. Et spørgsmål fra Komitéen under mødet i Genève lød 
derfor: 'Vær venlig at oplyse antallet af hjemløse og giv information om tvangsflytninger i kinesiske byer!' Svaret var mest en gentagelse af rapportens oplysninger om, hvad regeringen har gjort for at beskytte retten til en bolig, hvor meget den gennemsnitlige boligstørrelse er steget i de seneste 20 år etc.

Under den mundtlige behandling henviser et af Komitéens medlemmer flere gange til, at det skriftlige svar ikke giver oplysninger om antallet af hjemløse. Han mødes til sidst med en kategorisk afvisning: "Der findes ikke hjemløse i Kina - af den grund (tvangsflytninger). Tak for Deres omsorg!"

I Komitéens 'Konkluderende Observationer' finder man herefter følgende vurdering og anbefaling: "Komitéen beklager utilstrækkelig information om omfanget af og grundene til hjemløshed i medlemslandet" og "Komitéen anbefaler, at medlemslandet øjeblikkeligt tager skridt til at sikre tilstrækkelig kompensation og genhusning af personer, som bliver flyttet fra deres hjem...".

\section{Det asiatiske eksempel}

Som eksempel på staternes råderum i forbindelse med beskyttelsen af socioøkonomiske rettigheder kan nævnes udviklingen i Asien, som på afgørende vis har udfordret den vestlige tankegang omkring stat og velfærd. Den voldsomme økonomiske vækst i mange asiatiske lande har ikke, som forventet, medført dannelsen af velfærdssystemer, som vi kender dem, men det er alligevel lykkedes regeringerne at etablere forbedringer i sociale forhold og opnå en vis udjævning af indkomstforskellene.

Væksten i den asiatiske økonomi begyndte i Japan efter Anden Verdenskrig og fortsatte i de såkaldte 'fire små tigre' - Taiwan, Hong Kong, Singapore og Sydkorea - fra midten af 1960'erne. Malaysia, Filippinerne og Thailand er også ved at bevæge sig op i gruppen af mellemindkomstlande I disse områder er en eksplosiv økonomisk vækst blevet gennemført under politisk stabile styrer og fulgt af en stadig større lighed i indkomst uden store investeringer i sociale sikkerhedsnet. Altså høj vækst og lave sociale udgifter har medført større økonomisk lighed. En ideel udvikling, set med politiske briller.

Det 'asiatiske mirakel', som det blev kaldt, tiltrak sig da også interesse i Vesten blandt forskere og politikere, der beskæftigede sig med socialpolitiske reformer. Nogle pegede ligefrem på modellen som en mulig velfærdsmodel for de vestlige lande! Vurderingen skiftede dog noget under den store økonomiske krise i 1997, som medførte social elendighed i nogle af de asiatiske lande.

Men diskussionen udviklede sig til spørgsmålet, om der eksisterede en speciel form for asiatisk velfærdsmodel med betegnelser som 'velfærdsorientalisme'; 'den konfucianske 
velfærdsstat'; 'social-orientalisme' eller andre kombinationer af ordene orientalsk/konfuciansk og velfærd.

De fleste svarer dog benægtende på spørgsmålet, selvom de er enige om, at der findes særlige træk i de asiatiske sociale systemer, som udspringer af deres fælles udgangspunkt med kombinationen af en hurtig vækst og politisk enevælde. Men hvad enten man definerer det som en særlig type eller ej, er alle enige om at velfærdsystemerne i disse lande er karakteriseret ved

- Et autoritært politisk styre

- Lave offentlige udgifter til social forsorg

- Ansvaret placeret hos familien eller nærmiljøet

- Ringe vægt på rettighedsaspektet

- Ringe muligheder for folkelig deltagelse.

Undersøgelserne har rokket ved et dogme i tidligere socialpolitisk teori, nemlig at et demokratisk styre er et nødvendigt resultat af industrialisering og en nødvendig forudsætning for bekæmpelse af social ulighed. Et vigtigt spørgsmål er her statens rolle, som er anderledes end den har været i den europæiske udvikling.

I konfucianske samfund er støtte til mindrebemidlede og andre so ciale opgaver en pligt for eliten, og denne pligt iscenesættes og håndhæves af de offentlige myndigheder, som med forskellige virkemidler sørger for, at eliten (dvs. ikke blot formuende individer og familier, men også store virksomheder) opfylder sin pligt over for samfundet. Staten opretter og støtter med skattefritagelse og andre midler fundraising hos private eller sociale organisationer i et langt større omfang end herhjemme. Og staten påbyder i nogle tilfælde opsparings- og forsikringsordninger på markedsvilkår, igen tiltag man også finder i europæiske lande, men med langt ringere betydning.

Det største land i regionen, Kina, er for eksempel med forbillede i de 'fire små tigre' nu i gang med at etablere sociale forsikringsordninger, der favoriserer folk i arbejde, og udsteder meget ringe velfærdsgarantier til folk uden for arbejdsmarkedet eller bønderne. Som ses i observationen om Kina, kommenteres bøndernes ringe sociale sikkerhedsnet, men der sættes ikke spørgsmålstegn ved selve principperne bag de nye strukturer. Heller ikke i observationerne om Japan eller Hong Kong nævnes det, at en stor del af statens ansvar i realiteten er delegeret ud til civilsamfundets forgodtbefindende!

\section{Det vanskelige krydsfelt}

Hvordan forholder det internationale system til beskyttelsen af sociale rettigheder sig til de faktisk førte sociale politikker i de lande, der er tiltrådt Konventionen? Som vi har set er det menneskeretlige system temmelig liberalt i forhold til politiske og økonomiske systemer. En gen- 
nemgang af de 15 konkluderende observationer viste, at det internationale system (hvis holdning må siges at komme til udtryk gennem Komitéens anbefalinger) både vurderer resultatet af de forskellige regeringers foranstaltninger, kommenterer staternes handlemåde og mangel på samme og endelig drager regeringerne til ansvar for holdninger i befolkningerne, som ikke er i overensstemmelse med konventionens indhold.

Spørgsmålet om, hvorvidt Komitéen 'blander sig' i de enkelte landes politiske og økonomiske systemer, kan således ikke besvares entydigt. Der er en indbygget modsætning imellem at være politisk 'neutral' og samtidig kræve et politisk system baseret på folkelig deltagelse og kun acceptere begrænsninger, der er 'nødvendige i et demokratisk samfund.' Ifølge dokumenternes ordlyd udgør et udemokratisk system en krænkelse af Konventionen.

Dette medfører dog ikke, at lande med udemokratiske systemer udelukkes, eller at deres autokratiske politiske system som sådan påpeges $\mathrm{i}$ de konkluderende bemærkninger. Komitéen synes at reagere på det modsætningsfyldte udgangspunkt ved at påpege manglende folkelig deltagelse på afgrænsede, konkrete områder, men ikke tage stilling til det politiske eller økonomiske sy- stem i dets helhed og sammenhæng. Det bemærkes, at Komitéen heller ikke 'giver karakterer' eller rangordner de forskellige lande i forhold til hinanden.

En gennemlæsning af dette udvalg af autoritative ytringer fra det internationale system viser, hvordan dets repræsentant, Komitéen for $\varnothing$ konomiske, Sociale og Kulturelle rettigheder, mere arbejder gennem en dynamisk påvirkning, en konsultativ proces, end gennem kategorisering af enkeltlande og udmåling af sanktioner. Tonen i observationerne er yderst urban. De positive aspekter bliver fremhævet først, derudover udtrykkes der 'bekymring', eller i få tilfælde 'bestyrtelse', men aldrig kritik eller fordømmelse.

Ligeledes udtrykkes det ikke, at der foreligger en krænkelse eller et brud på konventionen. Hermed kan man jo ikke konkludere, at de behandlede lande ikke krænker Konventionen; det gør de øjensynligt alle sammen mere eller mindre og på forskellige områder. Men denne del af systemet har ikke mandat til at kræve specifikke politikker gennemført eller særlige institutioner oprettet, dens rolle er udelukkende vejledende og støttende.

Hatla Thelle er sinolog, historiker og seniorforsker på Institut for Menneskerettigheder. 